\title{
A NAGYSZOMBATI EGYETEM PEDAGÓGIAI KARA
}

Szerzők:

Pšenáková Ildikó (PhD)

Trnavská univerzita v Trnave

(Szlovákia)

Szerző e-mail címe:

ildiko.psenakova@gmail.com
Lektorok:

Stoffová Veronika (prof., CSc)

Trnavská univerzita v Trnave

(Szlovákia)

Pokorný Milan (PhD)

Trnavská univerzita $\mathrm{v}$ Trnave

(Szlovákia)

...és további két anonim lektor

\section{Absztrakt}

Mivel a Nagyszombati egyetem Pedagógiai kara részt vett a $\mathrm{K}+\mathrm{F}$ Stúdió Kft. által megrendezett 4. és 5. nemzetközi interdiszciplináris konferenciák szervezésében egy kicsit közelebbről is be szeretnénk mutatni egyetemünket, illetve karunkat. Cikkünkből kiderül, hogy az egyetem története magyar gyökereken alapul.

Kulcsszavak: Nagyszombati Egyetem, Pedagógiai Kar, oktatás, kutatás

Diszciplina: pedagógia

\section{Abstract}

FACULTY OF EDUCATION OF TRNAV A UNIVERSITY

As the Faculty of Education of the University of Trnava participated in the organization of the 4th and 5th international interdisciplinary conferences organized by $\mathrm{K}+\mathrm{F}$ Studio Kft. We would like to present our university and faculty in a little more detail. Our article reveals that the history of the university is based on Hungarian roots.

Keywords: University of Trnava, Faculty of Education, education, research

Disciplines: pedagogy

Pšenáková Ildikó (2020): A Nagyszombati Egyetem Pedagógiai Kara. OxIPO - interdis₹ciplináris tudományos folyóirat, 2020/2, 97-101. doi: 10.35405/OXIPO.2020.2.97 


\section{Rövid történelem}

A Nagyszombati Egyetem (Trnavská univerzita v Trnave) Szlovákia egyik legrégebbi egyeteme. Ebben az évben emlékezünk meg az elődje megalakulásának 385-ik évfordulójáról. Az egyetem elődjét Pázmány Péter bíboros alapította 1635ben. Ennek négy kara volt: teológiai, filozófiai, jogi és orvostudományi, és a jezsuiták vezették.

Az egyetem hírnevét elsősorban a csillagvizsgálónak köszönhette, amelyet Kéri Borgia Ferenc, jezsuita csillagász, matematikus, klasszika-filológus, egyetemi tanár és az egyetem rektora alapított, de a hírnévhez hozzájárult az egyetemi könyvtár, a nyomda és egyetem kertje is. A történelmi Nagyszombati egyetem 142 évig működött a városban, míg 1777-ben áthelyezték Budára, Magyarország akkori központjába (Net1, Net2).

Az Egyetem alapításának 385. évfordulója tiszteletére logó lett tervezve, amelynek háttérét az 1742-es naptárban használt Franz Leopold Schmittner metszete ihlette. A logót (1. ábra) önmagában vagy az egyetem jelenlegi logójával (2. ábra) együtt ajánlott használni a 2020. naptári évben (Net3).

A kommunizmus bukása után a Szlovák Nemzeti Tanács 1992. március 25.-i döntése alapján, 1992. július 1.-én újra megnyílt a Nagyszombati egyetem. Az Akadémiai tanács 1992. szeptember 1.-én két kart hozott létre a Bölcsészettudományit és a Pedagógiait.
Az Ápolási és szociális munka kart 1994-ben alapították, de 1998-ban a karnak a neve megváltozott Egészségügyi és szociális munka karra. 1997. október 23.án alapították meg a Teológiai kart és 1997. november 1.-én a Jogi kart. Így ma az egyetem öt karral rendelkezik, közel 5000 hallgatóval és több mint 32000 végzet diplomással (Net1).

1. ábra: Az egyetem évfordulójára készüllt logó (forrás: Net3)

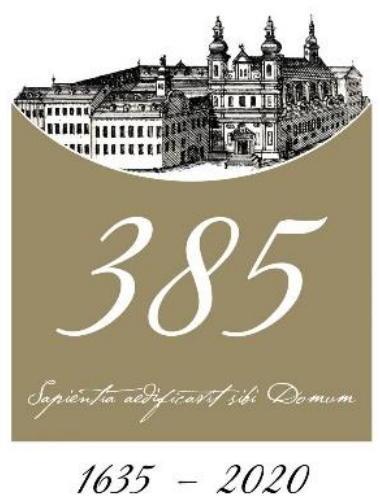

2. ábra: Az egyetem jelenlegi logója (forrás: bttps:/(www.truni.sk/)

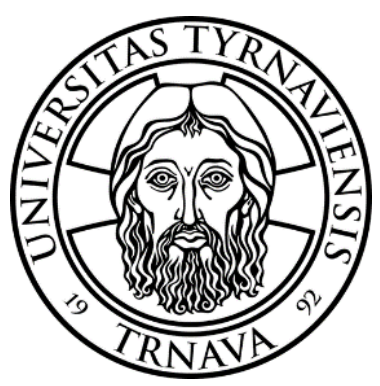


Az Egyetem $m a$ is követi az eredeti egyetem híres történelmét, értékeit és örökségét, amely a keresztény hagyományokon alapult és mint a közép-európai régió egyik oktatási központja Trnava (Nagyszombat) városát és környékét európai kontextusba helyezte.

\section{A Pedagógiai Kar}

A Pedagógiai Kar (3. ábra), ahogy már említettük, a Nagyszombati egyetem két alapító karának az egyike volt. Alapszabályában a kar küldetése a következőképen lett meghatározva:

„a fiatalok oktatására és nevelésére, gondolkodásmódjuk fejlesztésére, érz̨elmi és erkölcsi szinvonaluk emelésére, utat mutatva egy demokratikus társadalomban való élethez, szolgáló tanárok képzésére és formálására." (Net4)

3. ábra: A Pedagógia Kar logója (forrás: bttp://pdf.truni.sk/)

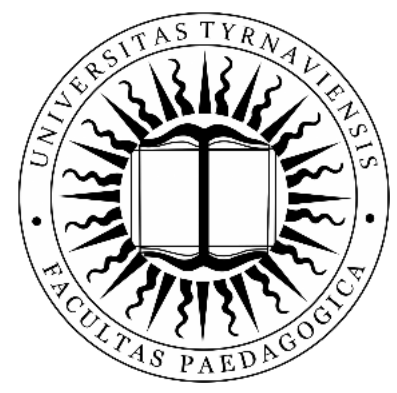

\section{Oktatás}

A Pedagógiai Kar az oktatás területén betartja Comenius elképzeléseinek pedagógiai örökségét, ugyanakkor használja és alkalmazza a legújabb tudományos ismereteket és progresszív trendeket a pedagógia és a hozzá kapcsolódó tudományágak területén, például pszichológia, szociológia, etika stb. A Kar tudományos iránya a tanárok és kutatók tudomány területeikre alapul, valamint a Kar, mint tanárképzési intézménynek a jellegére épül.

A Nagyszombati Egyetem jelenlegi öt kara közül, a Pedagógiai Kar az egyetlen, amely tanárképzést nyújt. A Kar garantálja és biztosítja a tanárképzést az óvodák, általános és középiskolák számára az egyes akkreditált oktatási programokban, valamint felkészíti a művészeti nevelés területén múködő szakembereket is.

A katolikus vallásnevelés tanárainak képzése az Egyetem Teológiai Karával együttmúködve történik. Ezt a szakot szakmailag a teológus kollégák garantálják. Ezen kívül a Pedagógiai Kar biztosítja a szociális pedagógia és nevelés szak nem tanári képzését is.

A kar oktatói tudományterületük szerint kilenc tanszékre vannak besorolva:

- Angol nyelv és irodalom tanszék

- Biológiai tanszék

- Kémiai tanszék

- Matematika és informatika tanszék

- Német nyelv és irodalom tanszék

- Pedagógiai tanszék

- Szépművészeti pedagógia tanszék 
- Szlovák nyelv és irodalom tanszék

- Iskolai pedagógia tanszék.

Az oktatási folyamatot korszerû múszaki berendezések, speciális laboratóriumok, stúdiók, audiovizuális eszközök, számítógépek, interaktív táblák és más didaktikai eszközök segítik.

A Pedagógiai Karon doktori képzés a következő doktori tanulmányi programokban folyik:

- Pedagógia

- Iskolai pedagógia

- Szlovák nyelv és irodalom

- A nyelv és az irodalmi oktatás elmélete

- A kémiai oktatás elmélete

- Összehasonlító irodalom

- A biológiai oktatás elmélete.

Az oktatás a Karon (de az Egyetemen is) nappali tagozaton történik, de egyes oktatási programok levelező (távutas) tanulmányok formájában is elvégezhe-tőek. A rendszeres felsőoktatás mellett a Kar oktatási tevékenységeket folytat a pedagógusok egész életen át tartó képzésében is.

\section{Kutatás}

Az oktatás mellett a másik fontos terület a Kar tudományos kutatása és művészeti tevékenysége. A hangsúly különösen az információs és kommunikációs technológiák alkalmazására és az oktatásra van helyezve, mivel csak így lehet lépést tartani a mai modern oktatással. Ezen kívül a kutatás az egyes tantárgyak oktatásának elméletére irányul, elsősorban pedagógiai-pszichológiai szempontból.

A Kar tudományos és pedagógiai profilja, valamint annak jó eredményei a hazai és nemzetközi intézményekkel való kapcsolatok kialakításában is tükröződnek. Elsősorban a Portugáliában, Belgiumban, Németországban, Magyarországon, a Cseh Köztársaságban és Horvátországban múködő egyetemi munkahelyekkel való együttműködésben valósul meg. Emellett civil szerevezetekkel (például: a magyarországi Kocka Kör Tehetséggondozó Kulturális Egesülettel (weblap: www.kockakor.hu), illetve cégekkel (például a K+F Stúdió Kft.-vel - weblap: www.kpluszf.com) együttmúködve veszünk részt nemzetközi interdiszciplináris konferenciák szervezésében (Mező és Mező, 2020).

A Kar további fejlesztésének perspektívái és céljai összhangban vannak a felsőoktatási intézményekről szóló törvénnyel és a Szlovák Köztársaság felsőoktatási intézmények fejlesztésének koncepciójával.

\section{Zárszó}

Az UniRank értékelés 2020-ra vonatkozó eredményei szerint a Nagyszombati Egyetem a szlovák egyetemek rangsorában a 34 létező egyetem között a 9. helyet foglalta el, amely két hellyel jobb, mint 2019-ben. A Pedagógiai Kar pedig már 2012 óta a szlovákiai pedagógusokat kép- 
ző karok ranglistáján stabilan az első helyet foglalja el (Net3, Net4).

Reméljük, hogy a bölcsészettudo-mányokra orientált egyetemek között a Nagyszombati Egyetem továbbra is vezető szerepet fog betölteni a rangsorban.

\section{Irodalom}

Mező Ferenc és Mező Katalin (2020): V. Nemzetközi Interdiszciplináris Konferencia (Beszámoló). OxIPO - interdiszciplináris tudományos folyoirat, 2020/1, 59-70. doi: 10.35405/OXIPO.2020.1. $\underline{59}$

Net1: Trnavská univerzita: verná hodnotám, s úctou ke tradíciám, otvorená výzvam. Letöltés: 2020.04.23. Web: https:// www.truni.sk/univerzita
Net2: Kéri Borgia Ferenc. Letöltés: 2020.04.20. Web: https://hu.wikipedia .org/wiki/K\%C3\%A9ri Borgia Fere nc

Net3: Trnavská univerzita v Trnave predstavuje logo 385. výročia svojho založenia. Letöltés: 2020.04.24. Web: https://www.truni. $\underline{\text { sk/trnavska-univerzita-v-trnave-pred }}$ stavuje-logo-385-vyrocia-svojhozalozenia

Net4: História aposlanie. Letöltés: 2020.04.23. Web: http://pdf.truni.sk $\angle$ fakulta

Net5: Top Universities in Slovakia 2020 Slovak University Ranking. Letöltés: 2020.04.24. Web: https://www.4icu. org/sk/

Net6: UniRank 2020: Posunuli sme sa vyššie v rebrickeu slovenských univerzit. Letöltés: 2020.04.24. Web: https://www.truni. sk/unirank-2020-posunuli-sme-savyssie-v-rebricku-slovenskych$\underline{\text { univerzit }}$ 